\title{
Effects of Interest in Science, Study Habits, Sex and Level of Study on the Nature of Science Literacy Level of Undergraduate Chemistry Students of the University of the West Indies, Barbados
}

\author{
Leah Garner-O'Neale \\ The Faculty of Science and Technology, The University of the West Indies, Cave Hill Campus, Barbados \\ Email: leah.garner-oneale@cavehill.uwi.edu \\ Babalola Ogunkola \\ The School of Education, The University of the West Indies, Cave Hill Campus, Barbados \\ Email: babalola.ogunkola@cavehill.uwi.edu
}

\section{Doi:10.5901/jesr.2015.v5n2p267}

\begin{abstract}
In this study, the nature of science (NOS) literacy level of students enrolled in chemistry courses at the UWI-Cave Hill Campus as well as the effect of the students' general interest in Science, their study habits, level of study and sex on their level of NOS literacy was investigated. A descriptive survey research design was employed utilizing two instruments: the Predictors of Students' Knowledge of NOS Questionnaire and Wenning's NOS Literacy Test (NOSLiT). There were 80 students who participated in the study and the data collected was analyzed using the mean scores and standard deviations as well as ANOVA, t-test and linear regression at a 95\% confidence level. It was concluded that on average the chemistry students demonstrated good knowledge of the nature of science. There was statistical difference in the students' level of NOS literacy based on their study habits but not their sex, level of study or interest in Science. The joint contribution of variables to the students; level of NOS literacy was not significant however; their interest in Science was the greatest contributor.
\end{abstract}

Keywords: nature of science, chemistry, gender, interest in Science, study habits

\section{Introduction}

Scientific literacy has been investigated for many years by a variety of researchers from its inception in the 1950's (DeBoer, 2000). Much work has been done in defining "scientific literacy" as well as informing curriculum reform to achieve maximum scientific literacy in developed nations such as the USA, Britain and to some extent South Africa (Laugksch \& Spargo, 1999). The American Association for the Advancement of Science (AAAS) in 1989 thru Project 2061's Science For All Americans clarified a set of science education goals in the attempt to make all students achieve some level of scientific literacy. Many surveys have been undertaken and assessment tools devised to assist the process (Laugksch \& Spargo, 1996; Laugksch \& Spargo, 199; Shwartz etal., 2006; Wenning, 2006; Bybee etal., 2009). To date it has been understood that scientific literacy is multifaceted and multidimensional; it incorporates concepts and ideas from a variety of scientific disciplines and practices (Schwartz etal., 2006) but yet must be attainable by any citizen so that he or she may use scientific knowledge to inform day to day decisions (Wenning, 2006).

Pella et al in 1966 summarized the six most common defining elements of the term scientific literacy and are cited by Wenning (2006) as: Interrelations between science and society; ethics of science; nature of science; conceptual knowledge; science and technology; and science in the humanities. Of the top three, nature of science is of most interest since according to Wenning (2006), those who are nature of science (NOS) literate "possess knowledge of the content and history of at least one science discipline, plus knowledge of associated scientific nomenclature, intellectual process skills, rules of scientific evidence, postulates of science, science dispositions and major misconceptions about NOS".

Beyond many definitions of scientific literacy, Holbrook and Rannikmae (2009) suggests that the term is used metaphorically. Furthermore they outline that two viewpoints of scientific literacy exist. These are:

1. it's a central role for the knowledge of science and

2. it refers to its societal usefulness.

The first view point suggests that knowledge of science content is crucial if one is to be considered scientifically 
literate whereas the second point of view suggests that one needs to be scientifically literate in order to address and adapt to the challenges of an ever-changing world (Holbrook and Rannikmae, 2009).

Laugksch (2000) suggests that scientific literacy consists of three dimensions:

1. understanding of norms and methods of science

2. understanding of key scientific terms and concepts

3. an appreciation of the impact of science and technology on society

Abd-El-Khalick et. al. (1998) noted that scientific literacy refers to one's understanding of the concepts theories, principles and processes of science as well as their awareness of the relationship between science, technology and society as well as its complexities.

Overall, these suggest that the concept of scientific literacy has moved beyond the use of simple scientific problem solving and is about enabling individual citizens to adjust and participate in society (Holbrook and Rannikmae, 2009; Ozgelen et. al, 2013). Hence the emphasis on conceptual knowledge of the pure sciences is being de-emphasized and the ability to make decisions related to scientific and technological ideas and their related socio-scientific issues is being recognised as crucial elements (Holbrook and Rannikmae, 2009). Hurd (1998) outlines over twenty objectives which forms the criteria for a scientifically literate person.

One aspect of scientific literacy that most researchers agree on is that nature of science plays an important role in developing scientific literacy in that a scientifically literate person should have a functional understanding of the nature of science (Abd-El-Khalick etal, 1998; Hurd, 1998; Wenning, 2006; Holbrook and Rannikmae, 2009; Hodson and Wong, 2009). Abd-El-Khalick (2013) defines nature of science as understanding about science as a knowledge generation and validation enterprise".

Some agreed elements of nature of science is that its empirically based, subject to change (tentative), theoryladen, creative, subjective and a human endeavor which is influenced by society and culture (Lederman, 1992; Abd-ElKhalick etal, 1998; Miller etal, 2010). In addition, Abd-El-Khalick (1998) suggests that at the lower level, someone who is nature of science literate should be able to distinguish between observation and inferences and be aware of the relationship between laws and theories. Miller etal (2010) purports that a student's view of NOS can influence their performance, learning and hence academic achievement in science courses and that NOS can impact their interpretation of experiences and information throughout life as well as their personal, workplace and community decisions.

Much research has been done on NOS at various levels. Miller etal (2010) suggests that most of the research has been focused on the primary and secondary level teachers and their students although some concentrated on the college level and few on both. Research done at the primary and secondary levels include work done by Abd-El-Khalick etal (1998), Lederman (1999), Akerson etal (2000), Khishfe and Abd-El Khalick (2002) and Lederman etal (2012). Research done at the undergraduate level include Dagher and BouJaoude (1997) who looked at the scientific views of college students who were studying biological evolution and were enrolled in a senior Biology seminar; Abd-El-Khalick and Lederman (2000) who investigated the influence of a History of Science course on 166 undergraduates and graduate students and 15 pre-service secondary science teachers; Abd-El-Khalick (2006) who also looked at undergraduate and graduate students enrolled in a History of Science course and Parker etal (2008) who looked at the ideas of undergraduate atmospheric science students on the NOS.

Faculties at Universities throughout the world have been challenged to develop scientific literacy and specifically in some cases views of NOS to all students (Miller etal, 2010). This includes developing their foundational knowledge, critical thinking skills and their application of NOS knowledge to life (Lederman, 1992; Miller etal, 2010). The University of the West Indies is no exception (McKensie and Bell, 2004; UWI Strategic Plan 2012-2017)

Miller etal (2010) underscores that there seems to be a general consensus amongst all interested parties that elements of NOS should be included in all science curricula. There has been a difference of opinion in literature as to how the NOS literacy of students could be improved. Some researchers suggest that in order for students to increase their NOS literacy that it is important that they be taught NOS where as others think that they should be taught using principles of NOS. (Miller etal, 2010; Abd-El-Khalick, 2013).It is suggested that students can learn about NOS implicitly through engaging in various learning activities especially those based on inquiry (Brickman etal, 2009; Miller etal, 2010; Ozgelen etal, 2013) while others do not support this idea and think that NOS should be explicitly taught (Abd-El-Khalick, 1998; Lederman, 1999). Infact, Abd-El-Khalick amd Lederman (2000) investigated the impact of a History of Science course on students' conceptions of NOS but found that the course work does not necessarily enhance the student's view of NOS.

In order for teachers to adequately and carefully articulate or transfer knowledge of NOS they have to first 
understand it themselves (Abd-El-Khalick and Lederman, 2000). Teachers sometimes find it challenging however to translate their knowledge of NOS into their teaching practice. Out of a study done by Abd-El-Khalick etal (1998) he reported that many teachers thought that incorporating NOS into their teaching was vitally important because:

1. it would increase the students interest in science

2. it is imperative and shouldn't be separated from other aspects of science content and

3. it is regarded as the only way to convey science as a way of thinking to the students.

However, it was not seen in their lesson plans. This finding was supported by Lederman (1999) who also found that although teachers indicated that it was important to incorporate NOS concepts into their teaching it was evidenced that it was rarely considered when constructing their lesson plans or making instructional decisions. Lederman (1992) suggest that the relationship between teachers' knowledge and their ability to translate NOS into their practice can be complex and complicated. Some factors which can influence the process can be

1. pressure to finish the content of the course

2. organizational principles and classroom management

3. the ability of the students and their level of motivation

4. institutionally imposed constraints

5. teaching experience

(Lederman, 1992; Abd-El-Khalick, 1998; Lederman, 1999). It has also been suggested that the articulation of NOS in some documents used to support the curriculum is not an accurate reflection of the practicing scientists' perspective (Miller etal, 2010; Wong and Hodson, 2009) and even within certain science disciplines views vary somewhat (Dagher and BouJaoude, 1997; Bezzi, 1999).

Some research has been done specifically on the views of science students towards NOS (Parker etal, 2008; Lui and Tsai, 2008). Specifically Liu and Tsai (2008) found that the view of science-oriented undergraduates were really no different than the non-science oriented undergraduates but that the views of the non-science students tended to be slightly more "sophisticated" when considering the theory-laden and culturally dependent aspects. It was suggested that this maybe as a result of how science is actually presented in the science classroom, in a "universal and objective" manner (Miller et.al, 2010).

Laugksch (2000) suggests that there are factors which can influence scientific literacy levels such as the level of science and math a student has completed as well as the specific science course they are undertaking. He found that students who did Physical Sciences tended to have an understanding of a larger number of important concepts in science than Biology students.

A students' overall interest in science may also have an effect on their knowledge of nature of science. Bulunuz and Jarrett (2010) suggests that a person's interest in a particular subject often begins in their childhood and is expressed through their play. It is suggested that the more interested one is in a particular area the more attentive and alert they become when engaged in its related activities; in addition they are more likely to engage in deeper cognitive processing (Tobias 1994). It must be noted that what is learnt about science is not solely related to what happens in the class room; in fact, a significant amount of learning occurs through other sources (Falk, 2002).

Studying is also important. It has been thought that there is a relationship between a student's academic achievement and their study habits (Aluja-Fabregat \& Blanch, 2004; Bashir \& Matto0, 2012). Gettinger \& Seibert (2002) noted a link between poor study habits and low academic achievement in that students with poor study habits tend to have poor achievement. According to Oluwatimilehin \& Oweyele (2012) the more time students spend studying material the more they retain it and ultimately achieve more in the area.

The questions that guided the research are as follows:

1. What is the level of NOS literacy among undergraduate chemistry students in the UWI, Cave Hill campus?

2. Is there any significant difference in the level of NOS literacy among undergraduate chemistry students at the UWI Cave Hill campus based on the following factors?
a. Level of study
b. Sex
c. Interest in science
d. Study habits

3. To what extent do the undergraduate chemistry students' level of study, sex, interest in science and study habits predict level of NOS literacy?

4. What is the relative contribution of each of the factors; level of study, sex, interest in science and study habits to the students' NOS literacy? 


\section{Overview of Methodology}

\subsection{Design}

The study employed descriptive survey research design. This design allowed the researchers to collect data regarding the participants' behaviours and opinion on the particular topic (Leacock, Warrican \& Rose, 2009; Creswell, 2008).

\subsection{Sample}

Purposive random sampling was utilized where all of the chemistry students in one of two chemistry classes from each level of study participated in the survey giving a total of eighty participants, sixty-four percent of the total population. Fiftyseven of the participants were male and twenty - three female.

\subsection{Instrumentation}

Two validated instruments were used in the study:

1. The Predictors of Students' Knowledge of Nature of Science Questionnaire (PSKNSQ)

2. The Nature of Science Literacy Test (NOSLiT)

The PSKNSQ was adopted from the Interest in Science Scale and the Study Habit Scale developed by Ogunkola (2011). It is divided into three sections: demographics, interest in science and study habits.

The interest in science and the study habits sections are four point Likert scale type where the participants were asked to indicate their opinion by choosing one of strongly disagree, disagree, agree or strongly agree after reading each statement. The interest in science section consisted of 15 items and the study habits section consists of 14 items.

NOSLiT is a 35 item assessment instrument developed by Wenning (2006) to measure students' understanding of the nature of science. It includes twenty-six multiple choice questions with four possible answers and nine true and false questions.

\subsection{Reliability and Validity}

The instruments were given to experts for suggestions and comments which were incorporated before administering. The Crombach alpha reliability coefficients of 0.636 and 0.500 were obtained for the Interest in Science and Study Habits sections of the PSKNSQ as compared to 0.723 and 0.755 as reported by Ogunkola (2011). Wenning (2006) reported the overall item difficulty for NOSLiT as approximately 0.66 with a KR20 reliability of 0.80 .

\subsection{Administration}

With the permission of the Head of the Department, all the chemistry students in one chemistry class from each level of study participated.

\subsection{Scoring}

The scoring of the Interest in Science Scale and the Study Habits Scale of the PSKNSQ was scored in the same way it was previously done by its developer Ogunkola (2011). Students with an interest in Science who scored between 15 and 38 were regarded as having low interest in science while those with scores 39 and over to a maximum of 60 were regarded as having high interest in science. Likewise those with a study habit score between 14 and 35 were regarded as having poor study habits whereas those with a score of 36 and over to a maximum of 56 were regarded as having good study habits.

\subsection{Data Analysis}

The data collected to answer research question 1 were analyzed using the mean scores, standard deviations and the minimum and maximum scores of the NOSLiT. For research question $2 \mathrm{a}$ ANOVA was used and for $2 \mathrm{~b}$ to $2 \mathrm{~d}$ t-test of independent samples was used. To answer questions 3 and 4 linear regression was utilized. A 0.05 confidence level was 
used throughout the data analysis.

\section{Results and Discussion}

\subsection{Research question 1}

What is the level of NOS literacy among undergraduate chemistry students at the UWI, Cave Hill Campus?

Table 1: Level of NOS Literacy

\begin{tabular}{|c|c|c|c|c|c|}
\cline { 2 - 6 } \multicolumn{1}{c|}{} & N & Minimum & Maximum & Mean & Standard deviation \\
\hline NOS literacy & 80 & 6.0 & 32 & 24.4 & 4.5 \\
\hline
\end{tabular}

Table 1 suggests that the average score for the chemistry students taking NOSLiT was 24.4 out of a possible 35 or 68.6 $\%$. This suggests that the chemistry students at the UWI Cave Hill campus are doing fairly well in terms of nature of science literacy since when compared to results from Wenning's study of 2006, Cave Hill's chemistry undergraduates did better than the Physics high school students (average score $=59.6 \%$ ) but not as well as their teachers (average score $=$ $84.8 \%$ ). This is understandable since undergraduates are at a higher stage of their study and hence exposure to scientific concepts than high school students but most likely less so than their teachers. Of some concern however, is the range of scores from $6(17.1 \%)$ to $32(91.4 \%)$. This suggests that not all students are at the same level of NOS literacy but the minimum score is too low and obviously unacceptable.

\subsection{Research question 2}

Is there any significant difference in the level of NOS literacy among undergraduate chemistry students at the UWI Cave Hill campus based on

a) Level of study

b) Sex

c) Interest in science

d) Study habits

\subsubsection{Level of Study}

Table 2: Influence of level of study on NOS literacy

\begin{tabular}{|c|c|c|c|c|c|}
\hline Variable & Sum of squares & df & Mean square & F & Sig \\
\hline Between Groups & 26.26 & 2 & 14.13 & 0.712 & 0.494 \\
\hline Within groups & 1509.23 & 76 & 19.86 & & \\
\hline Total & 1537.49 & 78 & & & \\
\hline
\end{tabular}

\subsubsection{Sex, Interest in Science and Study Habits}

Table 3: Comparison of Students' level of NOS Literacy based on their Sex, Interest in Science, and Study Habits

\begin{tabular}{|c|c|c|c|c|c|c|c|}
\hline Variables & Levels & $\mathbf{N}$ & Mean & Standard Deviation & df & $t$ & $\mathbf{P}$ \\
\hline \multirow{2}{*}{ Sex } & Female & 57 & 24.49 & 4.256 & \multirow{2}{*}{78} & \multirow{2}{*}{0.203} & \multirow{2}{*}{0.840} \\
\hline & Male & 23 & 24.26 & 5.362 & & & \\
\hline \multirow{2}{*}{ Interest in Science } & Low & 5 & 25.20 & 3.899 & \multirow{2}{*}{67} & \multirow{2}{*}{0.352} & \multirow{2}{*}{0.726} \\
\hline & High & 64 & 24.41 & 4.908 & & & \\
\hline \multirow{2}{*}{ Study Habits } & Poor & 58 & 24.95 & 3.526 & \multirow{2}{*}{74} & \multirow{2}{*}{2.138} & \multirow{2}{*}{0.036} \\
\hline & Good & 18 & 22.39 & 6.634 & & & \\
\hline
\end{tabular}

Tables 2 and 3 show that there were no significant differences in the level of NOS literacy among chemistry undergraduate students from UWI Cave Hill based on their level of study, sex and interest in science when investigated 
individually. However, there was a significant difference based on their study habits $(t=2.138, P=0.036)$. This suggests that level of study, sex and interest in science do not significantly affect students' knowledge of the nature of science.

Since nature of science is not directly taught as part of the chemistry curriculum this may explain why there is no significant difference as you move through the levels of the undergrad degree. Wenning (2006) did warn that unless the NOS content is directly taught scores on the test would be low. In addition, Martin-DeLeon (2010) reported that in the Caribbean by the time students reach the university level, female who enter science fields perform as well as or better than males.

It is surprising however, that interest in science has no significant effect on the participants' knowledge of nature of science. Abd-El-Khalick et.al (1998) suggested that teachers were of the opinion that incorporating NOS would result in a student's overall interest in science. In addition, as noted by Tobias (1994), Bulunuz and Jarrett (2010) and Ogunkola (2011) when someone has a high level of interest in science they tend not only to be attentive but more engaged in activity and with deeper cognitive processing. Since according to Wenning (2006) NOSLiT tests the content and history of at least one science discipline then it's expected that the more interested in science one is the higher their level of NOS literacy is expected to be.

There is a significant difference in terms of study habits. Ogunkola (2011) suggests that students with good study habits are more likely to have a higher level of achievement in science. Surprisingly however, in this study those with poor study habits have a higher mean score in nature of science literacy. This may be so because the students may be gaining knowledge from other sources such as magazines and television. As Falk (2002) suggests, learning science is not exclusive to school but a significant percentage of the learning occurs through non-school sources such as magazines, life experiences, TV, museums etc. based on the questionnaire one of the characteristics of someone who has poor study habits is that they study while listening to the radio and watching TV, sources from which they may gain scientific knowledge.

\subsection{Research question 3}

To what extent does the undergraduate chemistry students' level of study, sex, interest in science and study habits jointly predict their level of NOS literacy?

Table 4: combined effect of Students' level of study, sex, interest in science, and study habits on NOS literacy

\begin{tabular}{|c|c|c|c|c|c|}
\hline $\begin{array}{l}\text { R: } 0.214 \\
\text { R square: } 0.04 \\
\text { Adjusted R sq } \\
\text { Standard Error }\end{array}$ & 018 & & & & \\
\hline \multicolumn{6}{|c|}{ ANOVA } \\
\hline Model & Sum of squares & df & Mean square & $F$ & Sig \\
\hline Regression & 63.603 & 4 & 15.901 & 0.718 & 0.581 \\
\hline Residual & 1328.551 & 60 & 22.143 & & \\
\hline Total & 1392.154 & 64 & & & \\
\hline
\end{tabular}

The combination of the four variables accounted for 4.6 percent $\left(R^{2}=0.046, P=0.583\right)$ of the total variance in the students' nature of science literacy and was found not to be significant. This implies that the combination of the four variables does not contribute significantly to the students' nature of science literacy.

\subsection{Research questions 4}

What is the relative contribution of each of the factors; level of study, sex, interest in science and study habits to the students' NOS literacy? 
Table 5: Relative contribution of the predictor variables to the prediction of NOS literacy

\begin{tabular}{|c|c|c|c|c|c|}
\hline \multirow{2}{*}{ Model } & \multicolumn{2}{|c|}{ Unstandardized coefficients } & \multirow{2}{*}{$\frac{\text { Standardized coefficients }}{\text { Beta }}$} & \multirow{2}{*}{$t$} & \multirow{2}{*}{ sig } \\
\hline & B & Standard error & & & \\
\hline Constant & 18.100 & 7.385 & & 2.451 & 0.017 \\
\hline Study habit & -0.063 & 0.105 & -0.055 & -0.420 & 0.676 \\
\hline Level of study & -0.147 & 0.680 & -0.028 & -0.216 & 0.830 \\
\hline Sex & -0.929 & 1.338 & -0.090 & -0.694 & 0.490 \\
\hline Interest in science & 0.224 & 0.141 & 0.214 & 1.593 & 0.116 \\
\hline
\end{tabular}

The factor interest in science has the highest direct contribution to the level of nature of science literacy $(\beta=0.214)$. This was expected since as Bulunuz and Jarrett (2010) and Ogunkola (2011) suggest, students with high level of interest in Science tend to have higher achievement in science related test. The second highest contributor was sex $(\beta=-0.090)$ followed by study habits $(\beta=-0.055)$ then level of study $(\beta=-0.028)$. These all contributed indirectly to the participants' level of NOS literacy. The indirect relationship between level of study and NOS literacy is of particular concern since it suggests that, although the level of NOS literacy is not statistically significantly different among the levels, the first year students have the highest levels of NOS literacy and that the level of literacy tends to decrease as the students move through the University and hence they seem not to be continuously engaged in activities that will help them to build or maintain their NOS literacy.

\section{Conclusion and Recommendation}

On average the chemistry students demonstrated good knowledge of the nature of science however, the low minimum suggests that there are still students whose level of knowledge is way below what you would expect from science undergraduates. In addition the fact that the NOS literacy level does not significantly change as the students move through the institution suggests that there is no increase in NOS as the students progress through the chemistry program. In this regard it could be recommended that the NOS be formally introduced into the academic offerings of the Chemistry program and that activities which will assist in building NOS literacy be employed at all levels of study.

\section{References}

Abd-El-Khalick, F. (1998). The influence of history of science courses on students' conceptions of the nature of science. Unpublished doctoral dissertation, Oregon State University, Oregon.

Abd-El-Khalick, F. (2006). Over and over again: college students' views of nature of science. In: Scientific Inquiry and Nature of Science: Implications for Teaching, Learning, and Teacher Education,ed. L. B. Flick and N. G. Lederman, Dordrecht, The Netherlands: Kluwer Academic Publishers, 389-426.

Abd-El-Khalick, F. (2013). Teaching with and about nature of science, and science teacher knowledge domains. Science \& Education, 22(9), 2087-2107.

Abd-El-Khalick, F., Bell, R. L., \& Lederman, N. G. (1998). The nature of science and instructional practice: Making the unnatural natural. Science Education, 82(4), 417-436.

Abd-El-Khalick, F., \& Lederman, N. G. (2000). Improving science teachers' conceptions of nature of science: a critical review of the literature. International journal of science education, 22(7), 665-701.

Akerson, V. L., Abd-El-Khalick, F., \& Lederman, N. G. (2000). Influence of a reflective explicit activity-based approach on elementary teachers' conceptions of nature of science. Journal of Research in Science Teaching, 37(4), 295-317.

Aluja-Fabregat, A., \& Blanch, A. (2004). Socialized Personality, Scholastic Aptitudes, Study Habits, and Academic Achievement: Exploring the Link. European Journal of Psychological Assessment, 20(3), 157. Retrieved from http://web.udl.es/usuaris/e 7806312/grup/aaluja-archi/arti_aluja/pu_47.pdf. doi:10.1027//1015-5759.20

Bashir, I., \& Mattoo, N. H. (2012). A Study on Study Habits and Academic Performance among Adolescents (14-19) years. International Journal of Social Science Tomorrow, 1-5.

Bezzi, A. (1999). What is this thing called geoscience? Epistemological dimensions elicited with the repertory grid and their implications for scientific literacy. Science Education, 83(6), 675-700.

Brickman, P., Gormally, C., Armstrong, N., \& Hallar, B. (2009). Effects of inquiry-based learning on students' science literacy skills and confidence. International Journal for the Scholarship of Teaching and Learning, 3(2), 1-22.

Bulunuz, M., \& Jarrett, O. S. (2010). Developing an Interest in Science: Background Experiences of Preservice Elementary Teachers. International Journal of Environmental and Science Education, 5(1), 65-84.

Bybee, R., McCrae, B., \& Laurie, R. (2009). PISA 2006: An assessment of scientific literacy. Journal of Research in Science Teaching, 46(8), 865-883. 
Creswell, J. W. (2008). Educational research: Planning, conducting, and evaluating quantitative, $3^{\text {rd }}$ ed. Pearson Merrill Prentice Hall.

Dagher, Z. R., \& BouJaoude, S. (1997). Scientific views and religious beliefs of college students: The case of biological evolution. Journal of research in Science Teaching, 34(5), 429-445.

Deboer, G. E. (2000). Scientific literacy: Another look at its historical and contemporary meanings and its relationship to science education reform. J.Res.Sci.Teach., 37, 582- 601.

Falk, J. H. (2002). The contribution of free-choice learning to public understanding of science. Interciencia, 27(2), 62-65.

Gettinger, M., \& Seibert, J. K. (2002). Contributions of study skills to academic competence. School Psychology Review, 31(3), 350-365.

Holbrook, J., \& Rannikmae, M. (2009). The Meaning of Scientific Literacy. International Journal of Environmental and Science Education, 4(3), 275-288.

Hurd, P. D. (1998). Scientific literacy: New minds for a changing world. Science education, 82(3), 407-416.

Khishfe, R., \& Abd-El-Khalick, F. (2002). Influence of explicit and reflective versus implicit inquiry-oriented instruction on sixth graders' views of nature of science. Journal of research in science teaching, 39(7), 551-578.

Laugksch, R. C. (2000). Scientific literacy: A conceptual overview. Science education, 84(1), 71-94.

Laugksch, R. C., \& Spargo, P. E. (1999). Scientific Literacy of Selected South African Matriculants Entering Tertiary Education: A Baseline Survey. South African journal of science, 95, 427-432.

Laugksch, R. C., \& Spargo, P. E. (1996). Development of a pool of scientific literacy test-items based on selected AAAS literacy goals. Science Education, 80(2), 121-143.

Leacock, C., Warrican, S., Rose G. (2009). Research methods for inexperienced researchers. Kingston Jamaica: lan Randle Publishers.

Lederman, N. G. (1992). Students' and teachers' conceptions of the nature of science: A review of the research. Journal of research in science teaching, 29(4), 331-359.

Lederman, N. G. (1999). Teachers' understanding of the nature of science and classroom practice: Factors that facilitate or impede the relationship. Journal of research in science teaching, 36(8), 916-929.

Lederman, N. G., \& Lederman, J. S. (2012). Nature of scientific knowledge and scientific inquiry: Building instructional capacity through professional development. In Second international handbook of science education (pp. 335-359). Springer Netherlands.

Liu, S. Y., \& Tsai, C. C. (2008). Differences in the scientific epistemological views of undergraduate students. International Journal of Science Education, 30(8), 1055-1073.

McKenzie, C.; Bell, P. FOUN1210: Science, Medicine \& Technology in Society Course Material, UWI, 2004.

Miller, M. C. D., Montplaisir, L. M., Offerdahl, E. G., Cheng, F. C., \& Ketterling, G. L. (2010). Comparison of views of the nature of science between natural science and nonscience majors. CBE-Life Sciences Education, 9(1), 45-54.

Ogunkola, B. J. (2011). High School Student's Attitude to Use of Technology in Science Teaching, Interest in Science and Study Habits as Determinants of Science Achievement in Barbados. European Journal of Scientific Research, 65(4), 564-571.

Oluwatimilehin J \& Owoyele J (2012) Study habits and Academic Achievement in core subjects among junior secondary school students in Ondo State, Nigeria. Bulgarian Journal of Science and Education Policy, 6(1), 155-169.

Ozgelen, S., Hanuscin, D. L., \& YIlmaz-Tuzun, O. (2013). Preservice elementary science teachers' connections among aspects of NOS: Toward a consistent, overarching framework. Journal of Science Teacher Education, 24(5), 907-927.

Parker, L. C., Krockover, G. H., Eichinger, D. C., \& Lasher-Trapp, S. (2008). Ideas about the nature of science held by undergraduate atmospheric science students. Bulletin of the American meteorological society, 89(11), 1681-1688.

Pella, M. O., O'hearn, G. T., \& Gale, C. W. (1966). Referents to scientific literacy. Journal of Research in Science Teaching, 4(3), 199208.

Shwartz, Y., Ben-Zvi, R., \& Hofstein, A. (2006). The use of scientific literacy taxonomy for assessing the development of chemical literacy among high-school students. Chemistry Education Research and Practice, 7(4), 203-225.

Tobias, S. (1994). Interest, prior knowledge, and learning. Review of Educational Research, 64(1), 37-54.

University of the West Indies Strategic Plan 2012-2017. Retrieved from: http://www.cavehill.uwi.edu/resources/documents/ reports/uwi_strategic_plan.pdf.

Wenning, C.J. (2006) Assessing nature - of - science literacy as one component of scientific literacy. Journal of Physics Teacher Education Online, 2006, 3, 3-13.

Wenning C. J. (2007). Assessing inquiry skills as a component of scientific literacy Journal of Physics Teacher Education Online 4(2), 21-24.

Wong, S. L., \& Hodson, D. (2009). From the horse's mouth: What scientists say about scientific investigation and scientific knowledge. Science Education, 93(1), 109-130 